\title{
Liposuction in body-shaping treatment for Kobberling-Dunnigan syndrome
}

\author{
Lipoaspiração no tratamento do contorno corporal na síndrome de \\ Kobberling-Dunnigan
}

\author{
André Ratto Colombo \\ Bruna Ferrante Silva ${ }^{2}$ \\ Luiz Humberto Toyoso \\ CHAEM $^{3}$ \\ Adriano Peduti Batista ${ }^{1}$ \\ Cynthia OtTaiano \\ Rodrigues Almeida ${ }^{1}$ \\ Flávio Malaquias Amâncio ${ }^{4}$
}

Study conducted at Universidade Federal do Triângulo Mineiro, Uberaba, MG, Brazil.

Submitted to SGP (Sistema de Gestão de Publicações/Manager Publications System) of RBCP (Revista Brasileira de Cirurgia Plástica/Brazilian Journal of Plastic Surgery).

Received: July 26, 2009 Accepted: July 12, 2011

\begin{abstract}
Introduction: Kobberling-Dunnigan syndrome is characterized by a series of alterations in metabolism and body fat distribution. Body dysmorphism and the Cushingoid appearance may have negative social and psychological impacts on the patient, including difficulty with social adaptation. In such cases, liposuction is used with the aim of improving body contour, with consequent improvements in self-esteem. The results are long lasting when body weight is maintained. Case report: Liposuction of the back, abdomen, and cervical regions in a woman with Kobberling-Dunnigan syndrome led to significant improvement in her body shape, and the results were maintained nine months postoperatively.
\end{abstract}

Keywords: Lipodystrophy. Lipectomy. Syndrome. Lamin type A/genetics.

\section{RESUMO}

Introdução: A síndrome de Kobberling-Dunnigan caracteriza-se por um conjunto de alterações metabólicas e de distribuição da gordura corporal. O dismorfismo corporal e o aspecto cushingoide trazem repercussões psicológicas e sociais, com dificuldade de ajuste social. Nesses casos, a lipoaspiração é empregada com o objetivo de melhorar o contorno corporal e, consecutivamente, as alterações de autoestima. Os resultados apresentam-se duradouros quando há manutenção do peso. Relato do caso: Paciente do sexo feminino, portadora de síndrome de Kobberling-Dunnigan, submetida a lipoaspiração de dorso, abdome e região cervical, com melhora significativa do contorno corporal e manutenção dos resultados nove meses após a operação.

Descritores: Lipodistrofia. Lipectomia. Síndrome. Lâmina Tipo A/genética.

\section{INTRODUCTION}

Kobberling-Dunnigan syndrome is an autosomal dominant partial congenital lipodystrophy caused by mutations in the gene encoding a nuclear lamina protein, lamin $\mathrm{A} / \mathrm{C}$, which is associated with insulin resistance. Two forms of phenotypic manifestations have been described: type 1 , in which there is loss of subcutaneous fat confined to the legs, face, and trunk, along with muscle hypertrophy and normal genitalia, and type 2 , in which there is accumulation of fat in the entire trunk ${ }^{1-3}$.
The estimated prevalence of the Kobberling-Dunnigan syndrome is $1: 15,000,000$. This syndrome is observed only in females, according to genotypic studies conducted in five affected families (two Scottish and three German) ${ }^{1}$. This syndrome is thought to be of $\mathrm{X}$-linked dominant inheritance and fatal in the homozygous form $(\mathrm{XY})^{1,4}$. In the type 2 presentation, there is fat loss in the extremities and fat accumulation in the face, buttocks, abdomen, chest, groin, and axillary regions beginning during puberty, producing a Cushingoid appearance. There is also accumulation of fat in the viscera and muscles. The vulva is not affected, but there is hypertrophy of the vulvar outer lips ${ }^{1-3}$.

1. Plastic Surgeon, specialist member of the Brazilian Society for Plastic Surgery, Uberaba, MG, Brazil.

2. Resident Physician of the Plastic Surgery Service at Universidade Federal do Triângulo Mineiro, Uberaba, MG, Brazil.

3. Coordinator and Chairman of the Plastic Surgery Service at Universidade Federal do Triângulo Mineiro, Uberaba, MG, Brazil, Full Member of the Brazilian Society for Plastic Surgery, Uberaba, MG, Brazil.

4. Resident Physician of the General Surgery Service at Universidade Federal do Triângulo Mineiro, Uberaba, MG, Brazil. 
Insulin resistance arises before the clinical signs. A mutation in the nuclear lamin $\mathrm{A} / \mathrm{C}$ gene leads to shortages of adipose tissue in the periphery, which affects peripheral resistance to insulin due to a deficiency in the removal of plasma fatty acids ${ }^{1}$. There is a decrease in glucose consumption in the periphery, hyperinsulinemia, hypoleptinemia, and decreased adiponectin ${ }^{2,4,5}$.

The Kobberling-Dunnigan syndrome is also associated with type IV dyslipidemia, which leads to reduction of high-density lipoprotein cholesterol (HDL-cholesterol) and severe hypertriglyceridemia. This may subsequently cause the appearance of xanthomas and acute pancreatitis ${ }^{2}$. Later, liver damage and acanthosis nigricans may occur ${ }^{1,4}$. In some cases, hirsutism, menstrual abnormalities, and polycystic ovaries develop without reproductive malfunction. A higher incidence of hypertension and acute coronary heart disease can also be observed ${ }^{4}$.

The prognosis of this syndrome is related to metabolic (diabetes mellitus and dyslipidemia) and cardiovascular complications. Body dysmorphism found in these patients is often accompanied by serious psychological disorders, with the development of depression and social isolation ${ }^{4}$. Liposuction can be recommended to improve body contour and help minimize the stigma associated with this syndrome.

The present study reports the case of a patient with type 2 Kobberling-Dunnigan syndrome in whom liposuction was performed for the treatment of body dysmorphism. The patient showed clinical improvement and maintenance of the results in the late postoperative period.

\section{CASE REPORT}

A 26-year-old female patient was referred by the Service of Endocrinology from Universidade Federal do Triangulo Mineiro, Uberaba, MG, Brazil, with a diagnosis of Cushing's syndrome. Since the age of 12 years, the patient had full-moon facies, which was accentuated at the age of 18 years. She also had Hashimoto's thyroiditis since the age of 8 years and primary hyperparathyroidism since the age of 22 years. She was surgically treated after two episodes of hypercalciuria and renal colic. Over the last three years, she has been afflicted with insulindependent diabetes, chronic urticaria, and severe dyslipidemia. She was also being treated with tegretol for depression over the last four years. Menarche occurred at the age of 12 years, followed by regular menstrual cycles; contraceptives had been used over the previous two years.

On physical examination, her body weight was 46.6 $\mathrm{kg}$; height, $1.54 \mathrm{~m}$; and body mass index (BMI), 19.6. She presented with bilateral proptosis, lagophthalmos, Cushingoid facies, complete filling of the supraclavicular fossa, slight dorsal gibbosity, and dry and atrophic skin with no purple streaks. She also had centripetal lipodystrophy of the face, abdomen, flanks, and genitalia with hypertrophy of the labia majora (Figures 1 to 3 ).

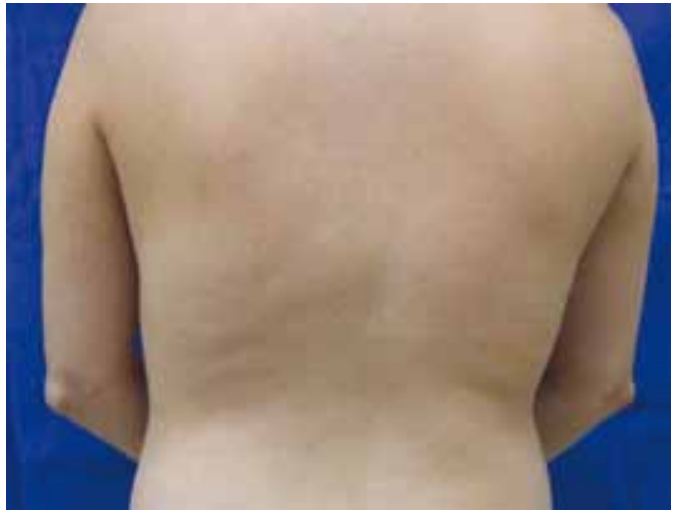

Figure 1-Dorsal region: preoperative.

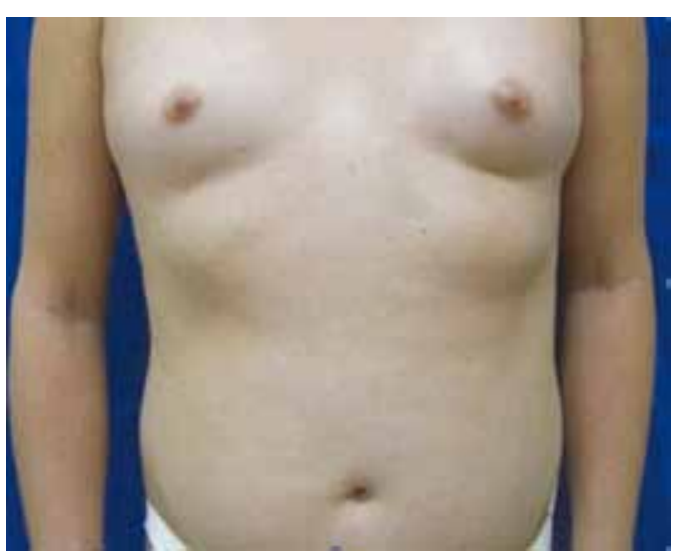

Figure 2-Abdominal region: preoperative.

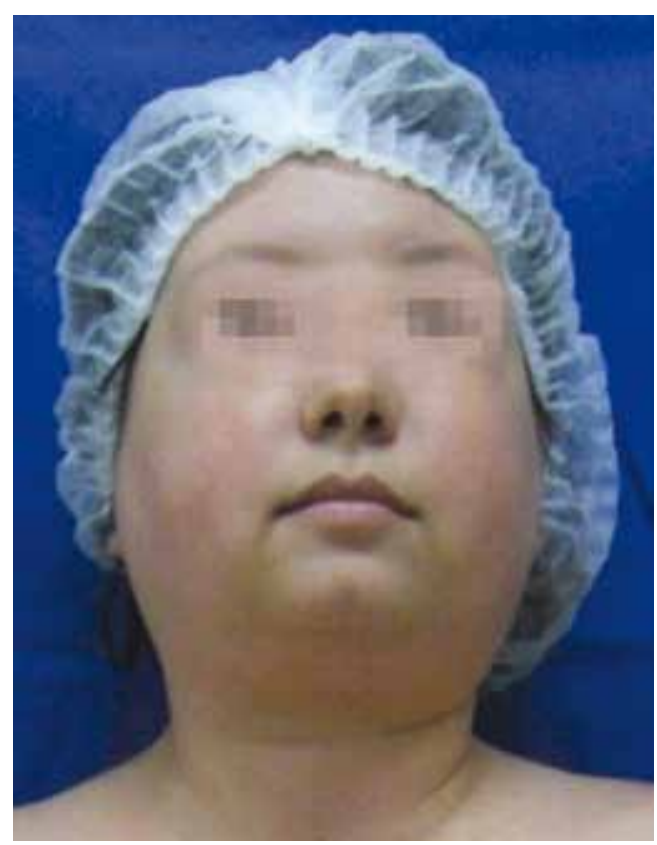

Figure 3 - Cervical region: preoperative. 
Liposuction under general anesthesia was recommended for the treatment of body lipodystrophy. She had significant visceral fat accumulation that hampered determination of abdominal wall thickness, even after carrying out preoperative computed tomography.

Liposuction was started in the areolar layer, progressing to the lamellar area. The skin redundancy between tweezers allowed for the best estimation of the position of the aponeurosis of the abdominal wall. An infiltration of 2,000 $\mathrm{ml}$ of saline with epinephrine $(1: 500,000)$ was administered, and a volume of $3,000 \mathrm{ml}$ was aspirated from the abdomen, dorsal and cervical regions, and the labia majora.

The patient was discharged on the first postoperative day with a compression vest. She underwent manual lymph drainage after the first week.

There was improvement in body contour, with weight maintenance nine months postoperatively (Figures 4 to 6).

\section{DISCUSSION}

Congenital lipodystrophies are likely to cause serious psychological changes and increased morbidity. In type 2 Kobberling-Dunnigan syndrome, the changes begin at puberty, causing patients to feel less attractive and less feminine ${ }^{4}$. Periodic evaluations are necessary to maintain metabolic balance.

Liposuction is an important approach to normalize body contour and improve the patient's self-esteem ${ }^{1,4}$. In addition to the prevention of lipodystrophy reappearance, postoperative control of weight and diet may also prevent worsening of insulin resistance.

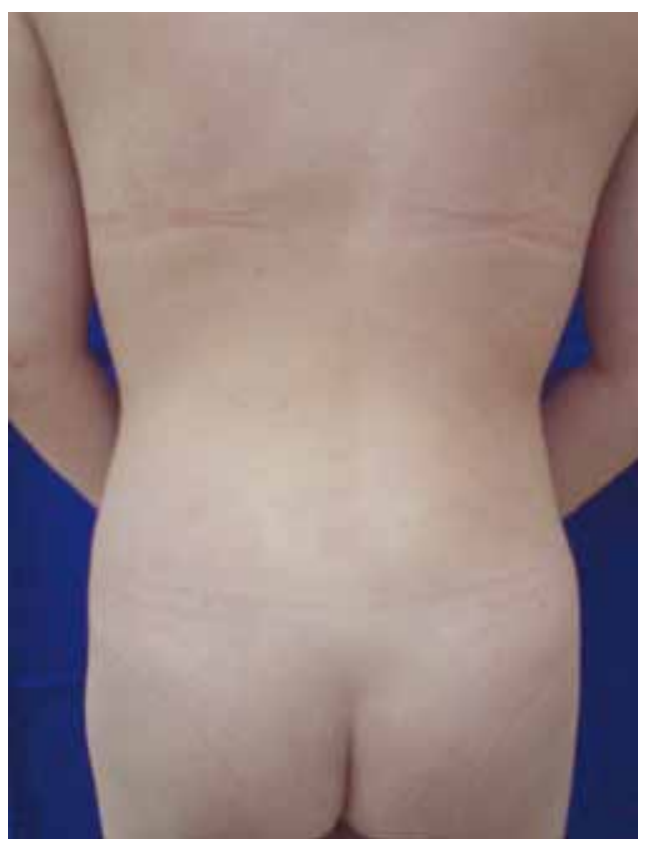

Figure 4 - Dorsal region: postoperative.

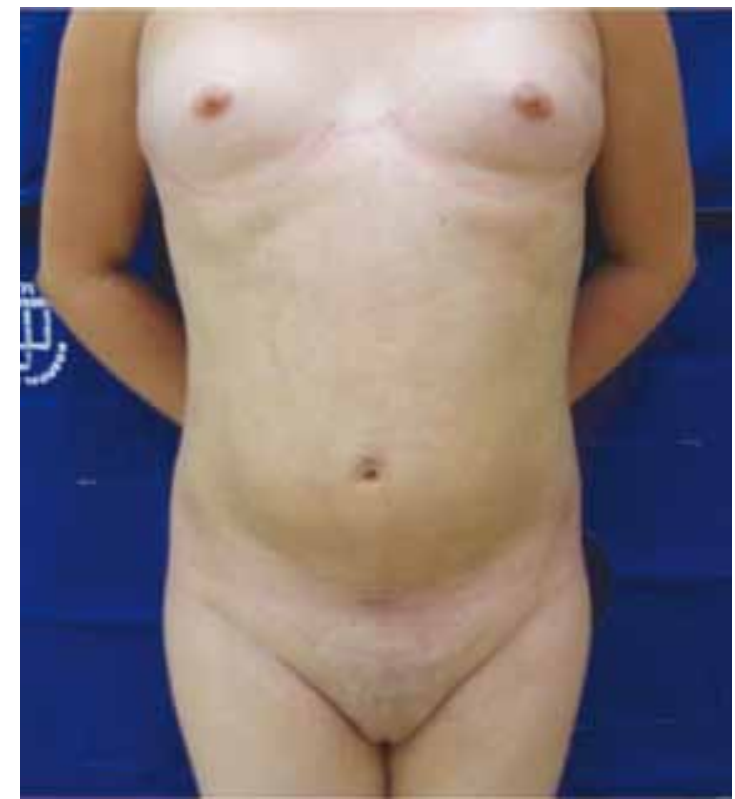

Figure 5 - Abdominal region: postoperative.

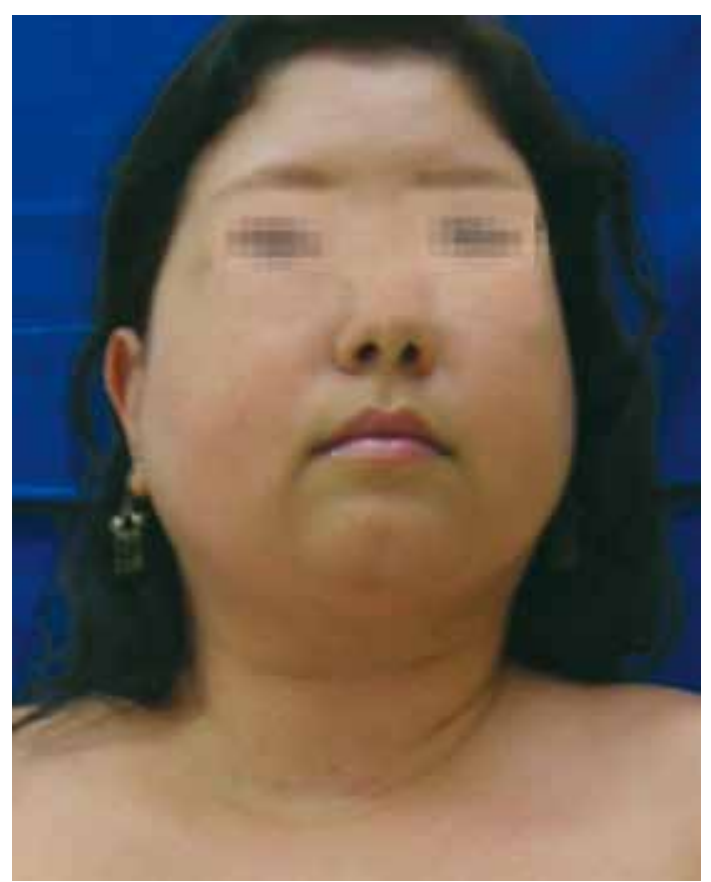

Figure 6 - Cervical region: postoperative.

\section{CONCLUSION}

Liposuction may be used to successfully treat the lipodystrophy found in the Kobberling-Dunnigan syndrome. Lasting results depend on weight maintenance, which requires proper control of diet and frequent endocrine evaluations. 


\section{REFERENCES}

1. Köbberling J, Dunnigan MG. Familial partial lipodystrophy: two types of an X linked dominant syndrome, lethal in the hemizygous state. J Med Genet. 1986; 23(2):120-7.

2. Monteiro MP. Causas genéticas. In: GEIR - Grupo de Estudo de Insulino Resistência da Sociedade Portuguesa de Endocrinologia, Diabetes e Metabolismo. Manual sobre insulino-resistência. 2aㅡ. Ledisboa: GEIR; 2006. p. 39-40.
3. Köbberling J, Tillil H. Empirical risk figures for first degree relatives of non-insulin dependent diabetics. In: Köbberling J, Tattersall R, eds. The genetics of diabetes mellitus. London: Academic Press; 1982. p. 201-9.

4. Jackson SN, Howlett TA, McNally PG, O'Rahilly S, Trembath RC. Dunnigan-Kobberling syndrome: an autosomal dominant form of partial lipodystrophy. QJM. 1997;90(1):27-36.

5. Toledo LS, Giovannetti M. Lipoaspiração e lipoenxertia nas deformidades do abdômen, dorso e flancos. In: Mélega JM, ed. Cirurgia plástica: fundamentos e arte. Rio de Janeiro: Guanabara Koogan; 2003. p. 629-38.
Correspondence to:

André Ratto Colombo

Av. Leopoldino de Oliveira, 2371 - ap. 602 - Uberaba, MG, Brazil - CEP 38015-000

E-mail: aratto.andre@gmail.com 